DOI: http://dx.doi.org/10.33846/ghs5403

\title{
Program Peduli Remaja untuk Meningkatkan Perilaku Mengatasi Anemia Defisiensi Besi pada Remaja
}

\author{
Yona C. Sahalessy (koresponden) \\ (Poltekkes Kemenkes Maluku; yonasahalessy@gmail.com) \\ Suardi Zurimi \\ (Poltekkes Kemenkes Maluku)
}

\begin{abstract}
ABSTRAK
Nutrisi pada masa remaja berperan penting dalam menentukan kesehatan di masa dewasa. Prevalensi remaja dengan anemia memang menunjukkan angka yang cenderung menurun. Namun demikian, masalah anemia defisiensi besi pada remaja masih memerlukan perhatian serius karena kemampuan remaja untuk melewati setiap tahap perkembangannya akan mempengaruhi kesehatan secara holistik. Penelitian ini bertujuan untuk memberikan gambaran penerapan program "Peduli Remaja" sebagai intervensi keperawatan untuk mengatasi anemia defisiensi besi pada remaja. Program "Peduli Remaja" diupayakan dengan edukasi kelompok sebaya melalui peran kader kesehatan remaja dan layanan nutrisi yaitu dengan pemberian jus jambu. Hasil evaluasi menunjukkan peningkatan skor pengetahuan, sikap, dan keterampilan remaja dalam pencegahan anemia. Edukasi kelompok sebaya dan layanan nutrisi dengan pemberian jus jambu memiliki pengaruh efektif dalam meningkatkan pengetahuan remaja dan perilaku diet yang tepat. Berdasarkan hasil evaluasi tersebut, upaya penerapan program "Peduli Remaja" memiliki pengaruh positif dalam meningkatkan perilaku terkait anemia defisiensi besi sehingga dapat menjadi rekomendasi dalam penangan masalah anemia gizi besi pada remaja puteri. Kata kunci: anemia; edukasi kelompok sebaya; remaja
\end{abstract}

\section{PENDAHULUAN}

\section{Latar Belakang}

Gizi adalah salah satu faktor yang menentukan kualitas sumber daya manusia. Kebutuhan gizi yang tidak tercukupi, baik gizi makro maupun gizi mikro dapat mengakibatkan pertumbuhan fisik yang tidak optimal, penurunan perkembangan kecerdasan, menurunkan produktivitas kerja dan daya tahan tubuh yang berdampak pada tingginya angka kesakitan dan kematian. Kecukupan gizi sangat diperlukan oleh individu sejak masih dalam kandungan sampai usia lanjut termasuk remaja. Jika remaja sehat secara fisik dan mental maka akan muncul suatu generasi yang mampu bersaing secara nasional maupun global dalam segala aspek (1).

Remaja merupakan populasi dengan potensi yang cukup besar dalam pengembangan penelitian kesehatan. Lebih lanjut dijelaskan oleh Stanhope \& Lancaster (2014) bahwa remaja adalah populasi beresiko terhadap tantangan kesehatan. Berbagai resiko kesehatan seperti penggunaan obat - obatan, kehamilan yang tidak diinginkan, merokok, berbagai penyakit menular maupun tidak menular adalah masalah kesehatan yang dihadapi juga oleh remaja termasuk anemia. Anemia bukan hanya diderita oleh ibu hamil namum merupakan masalah kesehatan tersendiri bagi remaja puteri dalam masa pertumbuhannya menjadi wanita dewasa ${ }^{(2)}$

Anemia merupakan masalah kesehatan global yang terjadi hampir di seluruh dunia dan diderita oleh lebih dari 2 milyar orang dengan prevalensi sekitar $80 \%$ pada perempuan. Data yang dilansir oleh WHO (2015) mengenai tingginya prevalensi anemia pada ibu hamil maupun remaja putri di seluruh dunia yaitu sebesar $38 \%$ pada ibu hamil dan $30 \%$ remaja puteri dan wanita. Salah satu artikel penelitian menjelaskan mengenai prevalensi anemia pada ibu hamil dan remaja puteri yang paling tinggi dipegang oleh negara - negara di Asia Tengah dan Asia Tenggara termasuk India dan Indonesia sebesar 64,7\% disusul negara di bagian Amerika Latin sebesar 62,3\%. Sementara Amerika dan Kanada menduduki angka prevalensi yag paling rendah yaitu hanya sekitar $2,9 \%$ (3)

Menurut data yang dirilis WHO, remaja menempati angka $18 \%$ dari total penduduk dunia $(\mathrm{WHO}$, 2015). Angka tersebut masih bisa berubah seiring dengan perubahan layanan kesehatan yang cukup baik pada dekade ini. Perubahan - perubahan yang terjadi selama masa transisi dari kanak-kanak ke dewasa membuat remaja harus menghadapi berbagai tantangan baik fisik maupun phsikis sehingga layanan kesehatan yang optimal sangat dibutuhkan untuk melewati masa tersebut. (4) 
Anemia menduduki peringkat ke empat dari sepuluh penyakit terbesar di Indonesia. Prevalensi anemia gizi besi secara nasional pada remaja puteri usia (13-18 tahun) sebesar 22,7 \%. Sedangkan dilingkup yang lebih kecil yaitu di Propinsi Jawa Barat remaja puteri penderita anemia yang didata pada tahun 2016 berkisar $31 \%$ dan hanya berbeda $7 \%$ bila dibandingkan dengan ibu hamil yang mengalami anemia. Artinya bahwa di Propinsi Jawa Barat remaja puteri dengan anemia hampir sebanding dengan ibu hamil yang mengalami anemia (Profil Jawa Barat, 2016). Kota Depok memiliki prevalensi remaja dengan anemia sebesar $36 \%$ berdasarkan data survey yang dilakukan oleh Dinas Kesehatan Kota Depok. Sementara di Kelurahan Curug Kecamatan Cimanggis belum ditemukan angka pasti penderita anemia remaja puteri, karena survey yang dilakukan terbatas pada ibu hamil. Namun tidak menutup kemungkinan angka kejadian anemia pada remaja puteri cukup tinggi. Hal ini dapat dijelaskan dengan hasil skrining yang dilakukan di tiga sekolah menengah atas di kelurahan Curug Cimanggis yaitu dari 200 siswa puteri yang diskrining kadar haemoglobinnya terdapat sekitar 48 remaja (24 \%) dari jumlah tersebut yang menderita anemia. Data ini tidak dapat dianggap sepele mengingat dampak jangka panjang maupun jangka pendek yang akan dialami oleh remaja puteri akibat anemia. ${ }^{(5)}$

\section{METODE}

Desain penelitian yang digunakan adalah quai experiment yang bertujuan mengetahui dampak intervensi Peduli Remaja terhadap perilaku terkait anemia defisiensi besi pada remaja puteri. Uji kelayakan/ ethical cleareance dilakukan oleh Komite Etik Penelitian Keperawatan Fakultas IImu Keperawatan Universitas Indonesia. Penelitian dengan tehnik pengambilan cluster sampling terdiri dari 68 remaja puteri yang teridentifikasi dengan anemia defisiensi besi dan tidak mengalami hambatan pendengaran dan bicara.

Sebelum dilakukan intervensi dilakukan pre-test lalu responden diberikan intervensi. Intervensi yang dilakukan merupakan penggabungan dari metode peer education dan pelayanan gizi (pemberian jus jambu) terdiri dari 3 fase pelaksanaan yakni fase awal, fase kerja, dan fase terminasi.

Instrumen pada penelitian ini berupa kuesioner yang terdiri dari 5 bagian, yaitu: karakteristik lansia dan demografi serta Dis-tress Diabetes Scale (DDS17 Bahasa Indo-nesia). DDS merupakan sebuah intrumen pengukuran distres diabetes yang dikem-bangkan oleh William $\mathrm{H}$. Polonsky berisi 17 pertanyaan sengan skala angka 1-6. Uji vali-ditas pada seluruh instrument didapatkan data tidak ada item yang kurang dari $0,3861(\alpha=0.05)$. Hasil uji reliabilitas $0,78-0,83$ untuk DDS yang berarti memiliki nilai keabsahan tinggi sehingga dapat diyakini keabsahannya.

\section{HASIL DAN PEMBAHASAN}

Hasil pengisian angket diperoleh hanya $72 \%$ remaja yang memiliki pengetahuan tentang anemia dan pencegahannya, $46 \%$ memiliki sikap yang baik dan $43 \%$ memiliki perilaku yang baik terkait pencegahan anemia. Berdasarkan hasil wawancara pada beberapa remaja puteri ditemukan bahwa pada umumnya remaja lebih memilih jajan di warung dan penjual keliling dari pada membawa bekal dari rumah. Remaja juga sering melewatkan sarapan pagi dan jarang mengkonsumsi makanan beragam terutama yang kaya zat besi seperti daging, sayur dan buah. Kebiasaan makan dan perilaku diet yang salah dapat berpengaruh pada munculnya kejadian anemia pada remaja. Penelitian Florescu, Temneanu, Nistor dan Mindru, (2016) memperkuat temuan tersebut dengan hasil penelitian pada sejumlah siswa di sekolah menemukan bahwa rata - rata siswa yang berisiko mengalami anemia besi adalah mereka yang menunjukkan kebiasaan makan yang salah dan sering melewatkan sarapan pagi sehingga kekurangan asupan zat besi.

Selain masalah pengetahuan, sikap dan perilaku remaja, belum tersedianya layanan kesehatan sekolah dan fasilitas penunjang lainnya juga menjadi faktor yang berhubungan dengan kejadian anemia pada remaja. Layanan kesehatan melalui UKS sekolah belum optimal dilaksanakan, demikian juga fasilitas penunjang seperti kantin sekolah yang sehat dan keamanan pangan yang terkontrol belum optimaal dilakukan.

Untuk menyelesaikan masalah anemia pada kelompok remaja, kemudian disusun intervensi program inovasi "Peduli Remaja" yang mengangkat edukasi kelompok sebaya dan pembrian jus jambu sebagai ide utama program ini. Kegiatan yang dilakukan baik perkelompok maupun perkelas pada program ini antara lain pelatihan guru UKS sebagai penangung jawab layanan kesehataan di lingkungan sekolah, pelatihan kader kesehatan remaja sebagai role model kesehatan, edukasi kesehatan tentang anemia dan pencegahannya baik perkelas maupun perkelompok, aktivitas fisik berupa yoga dan pemberian jus jambu sebagai terapi pengganti tablet Fe.

Program ini cukup berhasil dilaksanakan mengingat angka keberhasilan yang dicapai yaitu adanya penurunan kejadian anemia dari $18 \%$ pada pemeriksaan awal menjadi $7 \%$ pada pemeriksaan 
akhir. Terjadi pula peningkatan pengetahuan, sikap dan keterampilan sebelum dan sesudah intervensi yaitu; pengetahuan dari $72 \%$ menjadi $90 \%$, sikap dari $46 \%$ menjadi $71 \%$ dan perilaku dari $43 \%$ menjadi $54 \%$. Selain itu salah satu sekolah berhasil dinisiasi untuk pengadaan UKS yaitu SMK Semesta meskipun belum mencapai tahap yang diinginkan.

Merujuk pada model teori yang digunakan pada penerapan program ini keberhasilan yang dicapai cukup baik. Model teori WSCC yang menempatkan siswa sebagai focal point layanan kesehatan sekolah dengan memperhatikan salah satu prinsip utama yaitu setiap siswa harus sehat saat berada di sekolah, dan belajar mempraktikkan gaya hidup sehat. Model ini menekankan pada praktik layanan kesehatan komunitas sekolah berdasarkan sepuluh komponen yang terintegrasi diantaranya pendidikan kesehatan bagi siswa dan layanan nutrisi yang berkualitas dengan melibatkan peran komunitas, orang tua dan guru. Dengan menjadikan WSCC Model sebagai landasan teori, dikembangkan program inovasi keperawatan yang ditujukan untuk menangani masalah anemia pada remaja yaitu program "Peduli Remaja" dengan menggunakan metode edukasi sebaya dan pemberian jus jambu sebagai upaya promosi dan preventif.

Penggunaan metode edukasi kelompok sebaya menunjukkan dampak positif pada peningkatan pengetahuan, sikap, dan keterampilan remaja dalam perbaikan status gizi peningkatan kadar $\mathrm{Hb}$ dan perubahan pola diet. Hal ini sesuai dengan karakteristik psikososial remaja adalah mempunyai keterikatan dengan kelompoknya. Perkembangan sosial pada masa remaja lebih melibatkan kelompok teman sebaya dibanding orang tua. Sehingga peran kelompok teman sebaya terhadap perubahan perilaku remaja sangat besar. Walaupun remaja telah mencapai tahap perkembangan kognitif yang memadai untuk menentukan tindakannya sendiri, namun penentuan diri remaja dalam berperilaku banyak dipengaruhi oleh tekanan dari kelompok teman sebaya. Disinilah peran kader kesehatan remaja sebagai role model sangat penting untuk memberi pengaruh positif mengenai pola diet sehat dan kebiasaan makan yang benar pada remaja yang lain.

Metode edukasi sebaya juga dibuat bervariasi sehingga remaja yang lain tertarik untuk terlibat dalam proses edukasi. Penelitian yang dilakukan Savita, Nath dan Sharan (2013) memberi gambaran bahwa edukasi sebaya terhadap pencegahan anemia di pada remaja putri di India, mampu meningkatkan pengetahuan secara signifikan setelah satu bulan dilakukan intervensi. Intervensi edukasi gizi dilakukan melalui ceramah singkat menggunakan visual bantu (kartu flash, poster dan tampilan makanan mentah seperti makanan yang kaya zat besi, peningkat dan penghambat penyerapan zat besi) diikuti oleh diskusi.

Kelompok edukasi sebaya dibentuk di setiap sekolah dan setiap kelompok dipimpin oleh satu orang kader. Kelompok edukasi sebaya ini terdiri dari remaja puteri yang mengalami anemia, sehingga sesuai dengan pencegahan sekunder pada keperawatan komunitas. Pencegahan sekunder menekankan pada diagnosa dini dan tindakan untuk menghambat proses penyakit (Stanhope \& Lancaster, 2016).. Kelompok ini juga menjadi wadah berbagi informasi, tidak hanya untuk pencegahan anemia namun juga masalah kesehatan lain yang berkaitan dengan kondisi remaja. Sebagai panduan dan monitoring, dibuat buku kerja bagi remaja dengan anemia yang terlibat dalam proses kelompok, dan akan dievaluasi setiap minggu oleh perawat. Pada pelaksanaannya edukasi kelompok sebaya tidak dapat dilakukan secara optimal oleh kader, karena tingkat pemahaman dan pengetahuan yang berbeda. Pendekatan persuasive kepada remaja dengan anemia juga membutuhkan keterampilan komunikasi dan percaya diri yang tinggi dari kader. Oleh karena itu pelatihan kader kesehatan remaja secara kontinyu dapat dijadikan bagian dari program promosi kesehatan di sekolah oleh Puskesmas dan dinas terkait ${ }^{(6)}$

\section{KESIMPULAN}

Intervensi yang dilakukan untuk menangani masalah anemia defisiensi besi pada remaja putri adalah program "Peduli Remaja" mencakup edukasi kelompok sebaya yang melibatkan peran kader kesehatan remaja sebagai educator dan role model bagi kelompok sebaya juga pemberian jus jambu sebagai pengganti tablet Fe. Pendidikan kesehatan kemudian diupayakan terhadap kader kesehatan remaja dengan rangkaian edukasi nutrisi dan pencegahan anemia pada remaja puteri. Peningkatan perilaku terkait anemia defisiensi besi pada remaja putri setelah dilakukanya program Peduli Remaja menunjukkan kebrhasilan program yang dapat diterapkan sebagai salah satu upaya penanagan berkelanjutan di setting sekolah.

\section{DAFTAR PUSTAKA}

1. Siahaan G, Nainggolan E, Lestrina D. Hubungan Asupan Zat Gizi dengan Trigliserida dan Kadar Glukosa Darah pada Vegetarian. Indonesian Journal of Human Nutrition Brawijaya University; 
2015 Jun 28;2(1):48-60. Available from: http://dx.doi.org/10.21776/UB.IJHN.2015.002.01.5

2. Shah, S., Shah, P., Desai, S., Modi, D., Desai, G., \& Arora, H. (2016). Effectiveness And Feasibility of Weekly Iron and Folic Acid Supplementation To Adolescent Girls And Boys Through Peer Educators At Community Level In The Tribal Area Of Gujarat. Indian Journal Of Community Medicine, 41(2). http://Dx.Doi.Org/10.4103/0970-0218.173498

3. . Lopez, A., Cacoub, P., Macdougall, I. C., \& Peyrin-Biroulet, L. (2016). Iron deficiency anaemia. The Lancet, 387(10021), 907-916.

4. WHO. (2015). The global prevalence of anaemia in 2011.

5. Wibowo, N., Bardosono, S., Irwinda, R., Syafitri, I., Putri, A. S., \& Prameswari, N. (2017). Assessment of the nutrient intake and micronutrient status in the first trimester of pregnant women in Jakarta. Medical Journal of Indonesia, 26(2), 109-15. doi:10.13181/mji.v26i2.1617

6. Stanhope, M., \& Lancaste, J.D., (2016). Public health Nursing, $9^{\text {th }}$ ed. St Louis MO : Mosby- Elsevier 